\title{
Psychoeducational Groups Based on Dasa Pitutur from Sunan Kalijaga: An Indigenous Counseling to Enhance Other Group Orientation
}

(Kelompok Psikoedukasi Berbasis Dasa Pitutur Sunan Kalijaga: Konseling Indigenous untuk Meningkatkan Orientasi Terhadap Kelompok Lain)

\author{
Mulawarman Mulawarman*, Zakki Nurul Amin, Muslikah Muslikah, Sigit Hariyadi, Kusnarto \\ Kurniawan \\ Department Guidance and Counseling, Faculty of Education, Universitas Negeri Semarang, \\ Sekaran St., Semarang, Central Java, 50229 Indonesia \\ *corresponding author, e-mail: mulawarman@mail.unnes.ac.id
}

Article received: August $21^{\text {st }} 2020$; revised: November $24^{\text {th }} 2020$; accepted: February $5^{\text {th }} 2021$

\begin{abstract}
Some Western counseling approaches are not applicable in local cultures. Consequently, counselors have to accommodate the local culture to improve the efficacy of their services. This research aims to formulate indigenous counseling based on the Javanese culture of Dasa Pitutur from Sunan Kalijaga. Using that culture, the counselors are expected to improve the participants' cultural skills and respect for other cultures. It used the hermeneutic method with discourse analysis to interpret the messages' structure and pragmatic. The analysis result signifies that the Dasa Pitutur values are relevant with the other group orientation. The primary message taught in Dasa Pitutur is encouraging humans to comprehend their life journey and position to willingly and voluntarily accept their obligations and nature. Linear to their position as a social creature, they have to be aware of the essential values from their relationship, dependency, and appreciation toward other humans. This study can be an enrichment material of cultural values-based guidance and counseling science.
\end{abstract}

Keywords: psychoeducational, Dasa Pitutur, Sunan Kalijaga, other group orientation

\begin{abstract}
Abstrak: Layanan bimbingan dan konseling yang dipopulerkan dari Barat tidak semua sesuai dengan nilai-nilai lokal setempat. Oleh karena itu, konselor perlu mengakomodir nilai-nilai budaya setempat agar dapat menunjang keefektifan layanan yang diberikan. Tujuan penulisan ini adalah untuk merumuskan konsep konseling indigenous berdasarkan kearifan lokal suku Jawa yang bersumber dari Dasa Pitutur karya Sunan Kalijaga sebagai upaya untuk meningkatkan keterampilan budaya individu untuk respek terhadap kelompok lain. Kajian ini menggunakan metode riset hermeneutika dengan varian analisis wacana untuk menafsirkan struktur pesan dan aneka fungsi (pragmatik) bahasa yang terkandung dalam teks Dasa Pitutur. Hasil pengkajian ini menunjukkan bahwa nilai-nilai Dasa Pitutur relevan dengan orientasi terhadap kelompok lain. Nilai utama yang diajarkan dari Dasa Pitutur adalah mengajak manusia memahami perjalanan hidup dan posisi manusia untuk dapat menerima tugas atau kodrat dengan suka rela atau mengemban tugas dengan hati yang lapang. Selaras dengan prinsip manusia sebagai makhluk sosial yang menekankan hubungan antara satu individu dengan individu lain, dimana setiap manusia hidup bersama orang lain dan saling membutuhkan serta menghargai satu sama lain. Kajian ini berkontribusi sebagai bahan pengayaan teori wawasan dalam bidang ilmu bimbingan dan konseling yang berbasis nilai-nilai budaya.
\end{abstract}

Kata kunci: psikoedukasi; Dasa Pitutur; Sunan Kalijaga; other group orientation 


\section{INTRODUCTION}

The study of social justice in the educational field has become essential to be highlighted, primarily by multicultural counselors. As mentioned in the 21 st-century school counselor competencies, social justice advocacy is one of the counseling topics that demand a more significant concern since it bolsters counselors' learning in school (Dahir, 2009). Generally, counselors provide social justice counseling that focuses on some elements, such as academic, career, and interpersonal relations.

The expanding multicultural therapy issues involve culture, race, gender, sexual orientation, disability, religion, and socio-economic status. Sue and Sue (2008) stated that most counselors are trapped in their cultural conditioning. Consequently, they possess stereotypes and prejudice that unconsciously applied to counselees with different cultural backgrounds. Thus, they unknowingly neglect a particular population, predominantly the minority. Counseling and therapy are minimally used due to the trust issue, irrelevant perception, and extreme cultural sensitivity. Therefore, the multicultural counseling and social justice movement emerges as a solution for those cultural issues and challenges, as well as to enhance counselors' cultural sensitivity.

Investigation on interpersonal relations becomes an inseparable aspect of social equality discussion. As a social creature, prospective counselors always carry their cultural and socio-politic value in socially interacting with others (Matsumoto \& Juang, 2016). When counselors incorporate cultural and sociopolitical elements in their social process, it may create conflicts if the group members have no ability to adapt to other members' differences (Sue \& Sue, 2008). It is relevant to microaggression theory that explains individual differences can potentially trigger negative perceptions toward other individuals outside their group (Torino, Rivera, Capodilupo, Nadal, \& Sue, 2018). The impacts of that conflict lead prospective counselors to adopt an egalitarian social pattern or be in a group with individuals with similar cultures and socio-politics. This statement follows a theory that discloses college students frequently form their group based on similar interests and races or ethnic, especially for minority groups who are more comfortable being in a group with people from their race (Gloria \& Hird, 1999).

The process of this group formulation affects students' concept of themselves and their social environment in relation to interpersonal relations. Students who have been pleased with their group tend to identify that they belong to their group. The group members are commonly called in-group, while people outside that group are referred to as out-group (Matsumoto \& Juang, 2016). The presence of in-group and out-group may worsen the conflicts between groups. The group with strong culture bond values and class-bound values become the dominant group or the majority, while the group with weak values become the marginal group or the minority (Sue \& Sue, 2008).

The marginal group individuals have the opportunity to get negative labeling, stereotype, prejudice, stigma, and even discrimination if their existence and behavior do not correspond to the majority culture (Ahmedani, 2011; Dudley, 2000; Stuber, Meyer, \& Link, 2008). This stigma, prejudice, and discrimination carry considerable physical and psychological effects toward the victim (Ahmedani, 2011; Stuber et al., 2008). Thus, to avoid the issues and negative consequences from social injustice in cultural and socio-politic aspects, the prospective counselors have to get training or competencies enrichment on multicultural counseling to enhance their speaking skills and attitudes toward a minority group.

The ability and skills to effectively socialize with other groups are known as other group orientation. It represents the behavioral tendency exercised by an individual in interacting with other people outside their group (Phinney, 1992). Other group orientation is one aspect that should be promoted by the prospective counselors, as it is part of the interpersonal skills that reinforce their success in the academic and non-academic fields. Interpersonal skills are one of the ten skills required for prospective counselors to face the global competition in the 21st century (World Economic Forum, 2016). Therefore, guidance and counseling service that focuses on interpersonal skills development is essential to improve prospective counselor students' other group orientation understanding and skills. Meanwhile, psychoeducational group service facilitates the preventive and developmental means of the future counselor.

A psychoeducational group refers to a group service in the guidance and counseling that concentrates on preventing issues that originated from students' deficiencies (Henderson \& Thompson, 2016). Besides, this group also provides recent information and integrates it into new skills required by the prospective counselors (Berg, Landreth, \& Fall, 2018). Through this group, the counselor can present 
social equality advocacy service by advancing prospective counselors' (both from the minority and majority groups) understanding and skills to interact with people from outside their group effectively. Ardila, Sutoyo, and Mulawarman (2019) also identified that psychoeducational strategy with modeling technique improves social skills.

In this research, the psychoeducational group adopted local culture from the Dasa Pitutur (ten pearls of wisdom) of Sunan Kalijaga values. To improve the psychoeducational group service results, the counselor also accommodates the surrounding local values since not every western counseling approach corresponds to local matters. As discovered in research, Western counseling approaches also carry particular limitations, so some western approaches are not applicable to the local culture (Hariko \& Ifdil, 2017). Additionally, cultural distortion is one of the limited education service quality sources, including in counseling service. That distortion composes education that only focuses on rationality and innovation rather than creating an intellectual individual with noble character. The local culture should be adopted as the education's soul. From the perspective of education and service provision, local culture-based counseling should become one of the means to internalize students' character strengthening (Sugiharto et al., 2019).

Dasa Pitutur of Sunan Kalijaga is adopted as the local culture in this study. It encourages humans to fathom their life journey and position in this world to willingly receive their tasks and nature (Sakdullah, 2014). It is in line with human fundamental, as a social creature, that emphasizes individuals' relationships. The principle also highlights that humans live together and rely on each other. This wisdom contains the messages from Sunan Kalijaga that are used as the fundamental values taught and internalized through psychoeducational group counseling.

Using Dasa Pitutur based psychoeducational group counseling, this study is expected to be a theory enrichment material that widens guidance and counseling science, especially the ones related to qualified learning innovation with noble character. It is also expected to encourage prospective counselors to adopt local values as their counseling features, contrasting to western counseling. That way, the counselor can demonstrate Indonesia's local culture-based group intervention model toward the counselees and other stakeholders at the particular educational level.

\section{METHOD}

This study used the hermeneutic research method with discourse analysis on the messages' structure and investigation on the texts' pragmatics (Sobur, 2002; Strauss \& Corbin, 2013). In this study, the text of Dasa Pitutur from Sunan Kalijaga was translated into Nusantara counseling construct discourse. Using discourse analysis based interpretation, the text's content and the designated message can be retrieved. The obtained understanding may include the importance of the message and how the message is delivered and comprehended. Additionally, through this analysis, the concealed motive and interpretation can also be identified. According to Ricoeur, the hermeneutic method is applicable in analyzing literature presumed to have symbolic discourse due to its dominant fictionality, imagery, and metaphor (Sastrapratedja, 2012). In this study, the text was investigated as an extended form of other aspects. Meanwhile, the hermeneutic method was carried out through three main stages of symbolic comprehension, meaning allocation, and philosophical phases, as illustrated in Figure 1.

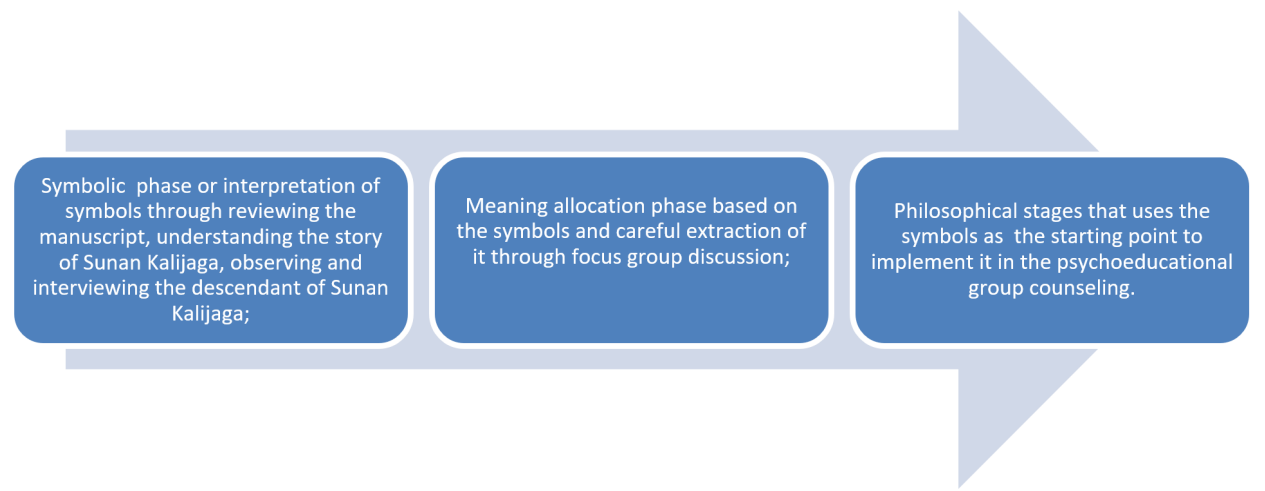

Figure 1. Stages of Hermeneutic Methods of Dasa Pitutur from Sunan Kalijaga 


\section{RESULTS}

The findings are categorized based on the reduced data, following the research focus to use Dasa Pitutur from Sunan Kalijaga to enhance other group orientation. The Dasa Pitutur values that is relevant for the other group orientation construct are presented in Table 1.

Table 1. Other Group Orientation from Dasa Pitutur Messages

\begin{tabular}{|c|c|c|c|}
\hline No. & Other Group Orientation & Dasa Pitutur Messages & $\begin{array}{c}\text { The Relevance of Dasa Pitutur } \\
\text { Values }\end{array}$ \\
\hline 1 & $\begin{array}{l}\text { Awareness to recognize their } \\
\text { culture }\end{array}$ & $\begin{array}{l}\text { Sura diro jayaningrat, lebur } \\
\text { dening pangastuti; Datan serik } \\
\text { lamun ketaman, datan susah } \\
\text { lamun kelangan }\end{array}$ & $\begin{array}{l}\text { Comprehend and accept } \\
\text { their true self, including their } \\
\text { tremendous and unacceptable } \\
\text { values and norms on them. } \\
\text { Understand their obligations as } \\
\text { an individual or a human as a } \\
\text { whole. }\end{array}$ \\
\hline 2 & $\begin{array}{l}\text { Awareness to appreciate other } \\
\text { people's culture }\end{array}$ & $\begin{array}{l}\text { Aja kuminter mundak keblinger, } \\
\text { aja cidra mundak cilaka }\end{array}$ & $\begin{array}{l}\text { Do not put their culture as } \\
\text { the best culture, and willingly } \\
\text { identify the differences between } \\
\text { cultures. }\end{array}$ \\
\hline 3 & $\begin{array}{l}\text { Understanding and respecting } \\
\text { the differences among } \\
\text { themselves and other ethnic } \\
\text { groups (including values, } \\
\text { principles, stereotypes, races, and } \\
\text { ethnocentric) }\end{array}$ & $\begin{array}{l}\text { Aja gumunan, aja getunan, aja } \\
\text { kagetan, aja aleman; Aja milik } \\
\text { barang kang melok, aja mangro } \\
\text { mundak kendho }\end{array}$ & $\begin{array}{l}\text { Adopt positive perspectives } \\
\text { in seeing differences and } \\
\text { understand that differences do } \\
\text { not always result in conflict. }\end{array}$ \\
\hline 4 & $\begin{array}{l}\text { Establishing the sense of } \\
\text { belonging and respecting each } \\
\text { other }\end{array}$ & $\begin{array}{l}\text { Memayu hayuning bawana, } \\
\text { ambrasta dur hangkara; Ngluruk } \\
\text { tanpa bala, menang tanpa } \\
\text { ngasorake, sekti tanpa aji-aji, } \\
\text { sugih tanpa bandha }\end{array}$ & $\begin{array}{l}\text { Can accept and appreciate } \\
\text { differences and attain positive } \\
\text { values and benefits from them. }\end{array}$ \\
\hline 5 & $\begin{array}{l}\text { Conducting activities together } \\
\text { with other groups }\end{array}$ & $\begin{array}{l}\text { Urip iku urup; Aja ketungkul } \\
\text { marang kalungguhan, kadonyan } \\
\text { lan kemareman; Aja adigang, } \\
\text { adigung, adiguna. }\end{array}$ & $\begin{array}{l}\text { Cultivate social feelings and } \\
\text { positive cooperation in the } \\
\text { activities with other groups to } \\
\text { obtain meaningful life. }\end{array}$ \\
\hline
\end{tabular}

\section{DISCUSSION}

\section{Indigenous Counselling Review: Psychoeducational Group Based on Dasa Pitutur from Sunan Kalijaga that enhances Other Group Orientation}

Psychoeducational can be defined as an intervention strategy given to individuals, families, or groups, focusing on self-development, emphasizing the means to exploit every aspect of their social supports (Walsh, 2010). The obtained finding describe that psychoeducational carries relatively positive effects, especially in the group, family, or social behavior intervention activity (Purbasafir, Fasikha, \& Saraswati, 2018; Putra \& Soetikno, 2018; Setiani \& Haryanto, 2019). In this study, the psychoeducational was focused on the group setting or is popular as psychoeducational group.

Mitchell and Gibson (2011) accentuate the psychoeducational group as an activity focusing on cognitive skills and behavior development that is conditioned to facilitate learning the designated knowledge and skills. The application of the psychoeducational group strategy is advisable for counseling compared to therapeutic intervention. It can be adopted in a short-term service or the service with a rather specific purpose.

Brown et al. (1993) bring a more expansive interpretation of psychoeducational strategy. They construe psychoeducational group strategy is applicable in various contexts and formats. One of the group models frequently implemented in psychoeducational with specific scope and information is the task group applied to complete a particular task in a developmental task. It aims to improve its participants' competencies in fulfilling their work and target. This service can be given to children, adolescents, or 
adults who prefer to transform their behavior based on each member's learning process or experiences, rather than the changes of self-awareness and self-understanding. Additionally, the implementation of psychoeducational group can be completed in one or more sessions, adjusted to their targeted results.

In this study, the psychoeducational group is also referred to as a learning or counseling group since it emphasizes an educational method to deliver the information and develop their skills. To improve the psychoeducational group results, this concept accommodates the local cultural values since not every western counseling approach is applicable. Western counseling approaches carry some limitations that inhibit their application in the local culture (Sumari \& Jalal, 2008). One of the proof is in Western life philosophy, a birth and development place of conventional counseling that is way different from Nusantara's Eastern culture. Western culture always promotes egalitarian or equality principle, while Eastern culture is close to paternalistic nature, respect for elders, and kinship living. Besides, the difference is also presented in the self-disclosure and problem disclosure in both cultures.

The internalization of cultural values during a counseling process is frequently named indigenous counseling (Kim, Yang, \& Hwang, 2010). It can also be specified as a scientific concept on unique and different human behavior originated from the surrounding local wisdom that is not adopted in other areas. It is exclusive since it is established in a particular group of society, adjusted to their situation. However, the application and internalization of those values neglect no counseling theoretical constructs that are universally from the West, such as psychodynamic, person-centered, cognitive approach, behavioristic, constructivist, and so forth. Those conventional approaches are intermittently combined with local culture, which is usually referred to as indigenous counseling.

Indigenous counseling services presented in this study is a psychoeducational group based on Dasa Pitutur from Sunan Kalijaga. It subsists ten direct messages from Sunan Kalijaga. The analysis results confirm that those messages teach the truth and noble and atrocious ethics, especially those embraced by Javanese. Dasa Pitutur possesses practical values for social life, consisting of life teaching that guides humans to behave ethically toward themselves and others. It is relevant to Sunan Kalijaga's teaching that encourages people to comprehend their life journey and position to willingly and sincerely accept their tasks and nature (Kaelany, 2000; Sakdullah, 2014).

This service aims explicitly to enhance other group orientation. This orientation is illustrated as individuals' orientation to others and their tendency to interact, and how far they interact with people from outside of their ethnic (Long, Zhu, Quan, Yang, \& Zheng, 2020). Their high appreciation for other groups carries a positive attitude and willingness to get in touch with other groups (Amin, Wibowo, Loekmono, Hariyadi, \& Isrofin, 2017; Phinney, 1992). The high orientation to other groups is presumed to bring a sense of belonging and support for others that reinforce people's living from different cultures.

This orientation is prompted by singular historical, contextual, and personal factors of each individual based on their experiences. Every person exercises behavior and attitude that follows their interaction and experiences obtained from others. Those aspects are inseparable since humans are social creatures who live and interact as part of a group and in a group (Myers \& Twenge, 2016). It is in line with the ethnical identity concept that once people in a group interact, they create a sense of belonging that affects their development and personality (Amin, Loekmono, Sofyan, \& Mulyawati, 2020).

This construct is essential, primarily in the current multiculturalism and globalization era. The relationship among individuals is one of the crucial topics because it affects someone's personal development. A group of society that upholds tolerance and appreciates difference is conducive for everyone's emotional development. Also, the strengthening of the behavioral concept and construct toward other groups is an effort to maintain the Eastern culture and tradition that welcome, respect, and condone other groups.

\section{Implementation of Indigenous Counseling: Psychoeducational Group Based on Dasa Pitutur from Sunan Kalijaga that enhances Other Group Orientation}

The implementation of Dasa Pitutur in this psychoeducational group is suitable for Indonesia's diversified cultures and races. This diversity can trap individuals into the bias, prejudice, and stereotype that may generate aggression. As explained in the microaggression theory, individuals can negatively prejudice other people outside their groups who have differences (Torino et al., 2018). Therefore, Dasa Pitutur from Sunan Kalijaga is relevant to be the topic of other group orientation. It encourages humans 
to comprehend their life journey and willingly carry their tasks and nature (Sakdullah, 2014). It is following human features as the social creature that accentuates their relationship with others. Humans have to live together, as well as rely on and respect each other.

Dasa Pitutur application within the psychoeducational group was carried out following the psychoeducational group stages of: (1) initial stage or establishment, (2) transition stage, (3) working stage, and (4) final stage (Corey, 2011; Gladding, 2016). In the initial stage, the counselor forms the psychoeducational group for the first time. During this stage, the counselor builds a relationship and actively communicates with the group members while also intensely understand the members' situation. The counselor's primary task in this phase is to create an activity that generates members' empathy and compliance to accept other members and shortly explain the activity's purpose.

In the transition stage, the group members frequently still feel awkward or anxious, so that they are still uncomfortable being around each other. Their feeling carries strain for their further activities. In this situation, the counselor becomes a facilitator who gives a perfect understanding and facilitates all members' involvement to accept each other's. The counselor is expected to release the tension using togetherness and warmth. In the next stage, the working stage, the counselor initiates the activity by explaining the material. The counselor asks the counselees to understand themselves, the cultural values, the society, and other factors, affecting their attitudes and behavior. Simultaneously, the counselees are encouraged to comprehend and fulfill their self-needs. It aims to generate group dynamics, introduce self-concept and their cultural values. The self-concept is established from an individual's cultural values. Meanwhile, in the final stage, the counselor declares that their activities have been completed and ensures that the next activity will be more enjoyable.

In this research, the implementation of psychoeducational counseling was completed in five sessions to accommodate all Dasa Pitutur values. In each of those sessions, the values from Dasa Pitutur relevant to the other group orientation were discussed.

\section{Session 1, Getting to Know Yourself}

The topic provided in this first session is the awareness to recognize their culture. Its objective is to let the members understand and welcome their true selves, including all of their tremendous and atrocious norms. The members are also expected to reflect adaptive behaviors by knowing themselves, their features, and their characters. This self-understanding becomes the starting point to comprehend their obligations as human beings (Ahmedani, 2011).

In this session, the "Sura diro jayaningrat, lebur dening pangastuti" is selected as the topic from Dasa Pitutur. That topic means that humans always live with desire and feelings that lead to maladaptive behavior, such as anger, hatred, stubbornness, and so forth. However, those feelings will vanish once humans can be wise and forgiving. Thus, one of the available interventions is by reflecting all group members' behavior and attitude and identifying the influence of culture in it. Additionally, the counselor also accentuates on "Datan serik lamun ketaman, datan susah lamun kelangan" message, which means that humans should not get easily irritated from any disasters they have encountered, or sad for losing a thing. In living, everyone experiences their lowest moment where they are in their worst situation. However, people are expected not to get caught in that situation or being irrational and feel vulnerable. Simultaneously, another message of "Aja ketungkul marang kalungguhan, kadonyan lan kemareman" means that humans should never be easily astounded, remorseful, or pampered. These messages advise people to take all of their conditions willingly, openly, and positively. Their life problems or deficiencies do not signify an impropriety. It is natural that humans face issues. It only depends on the ways individual interprets and comprehend themselves.

\section{Session 2, Get to Know Them}

Session two focuses on the awareness to recognize other people's culture. The group members are wished to identify their cultures and other members' culture, as well as the differences among them. The relevant concept from Dasa Pitutur is "Aja kuminter mundak keblinger, aja cidra mundak cilaka" that means human should not act like the smartest to avoid inaccurate directions, and they should also avert 
fraud acts. Culture awareness is frequently presumed to be the key that originates sense of belonging and adoration toward their culture and the appreciation and acceptance of the differences from other cultures (Amin et al., 2017; Matsumoto \& Juang, 2016).

In the cultural and other individuals discussion, the feeling of self-righteousness, best understands, and being the smartest frequently emerge. These feelings are originated from someone's stereotype (Ahmedani, 2011). Counselor is obligated to cultivate a humble attitude in every member. The counselor must clarify that comprehending the differences among the members helps them be wise in practicing better behavior and attitude during their social interaction. In short, this message instructs humans to adopt intelligent thought by avoiding being self-righteous. Additionally, it also explains the significance of being patient and humble to establish a positive relationship with great people from within or outside their group.

\section{Session 3 'Is There any Differences?'}

This session's primary theme is to figure out and appreciate the distinctness between themselves and other groups. It aims to help the members comprehend the essential of having an identity, a positive point of view toward differences, and the understanding that it does not trigger conflicts. Dissimilarity is not a differentiator that leads to conflict. There is nothing wrong with being different. It somehow widens their knowledge, experience, and live values. Indonesia's plurality is the nation's resources once the people welcome and respect each other's (Kamal, 2013).

In this third session, two messages are selected. The first message is "Aja gumunan, aja getunan, aja kagetan, aja aleman" which is translated into: human should not get easily impressed, amazed, felt remorse, or spoiled. The second is "Aja milik barang kang melok, aja mangro mundak kendho". It means that humans should not get tempted by luxurious, pretty, or beautiful, as well as not to consider polygamy, but to have full intention and passion. One of the human natural features is to admire new ideas outside of their knowledge. Their admiration is common, but this will turn into a considerably awful habit (Homan, 2013). In the previous session, the participants have been taught to avoid selfrighteousness and advised to be humble and appreciate information from other people. However, they should not get mesmerized by that new information.

The message of "Aja gumunan, aja getunan, aja kagetan, aja aleman" and "Aja milik barang kang melok, aja mangro mundak kendho" teach that dissimilarity and extensive sciences are common. Besides, it also tells that humans should not get perplexed or amazed by learning new ideas. The most significant concern for being dumbfounded learning new knowledge is the defeat that an individual's nescience made them inferior and dependent on others. Contrarily, humans have to recognize the existence of experience that they have not learned, and the knowledge they have comprehended may be a new idea for others. Humans' various intelligence, cultures, or other attribute build them to complete each other's.

\section{Session 4 'They, We, and I are One'}

This session emphasizes developing a sense of belonging and appreciating each other to train the members to accept and respect differences. Further, they are also encouraged to attain positive values and benefits from those differences. The Dasa Pitutur value adopted in this session is "Ngluruk tanpa bala, menang tanpa ngasorake, sekti tanpa aji-aji, sugih tanpa bandha". It means that humans should struggle without carrying troops, win without condescending or shaming others, commanding without bringing their power, wealth, or authority, and being affluent not because of their wealth. Individuals' perspective toward other groups unconsciously carries strong primordialism within themselves (Torino et al., 2018). This character unwittingly becomes a double edges sword. On one side, the individuals are confident with themselves, cultures, and values that shape their behaviors. However, it also causes them to have a narrow perspective toward other groups from only one singular cultural perspective. The learning from this message tells the members not to look down on people due to their differences.

In addition, the second message is "Memayu hayuning bawana, ambrasta dur hangkara". It explains that human should prioritize their safety, happiness, and welfare while also fight anger, greed, and avarice. Instead of contemplating the dissimilarities between cultures or values from other groups, they are encouraged to live their lives together. The message teaches that humans should consider safety, contentment, and prosperity as their common goals. Those goals can be obtained once everyone concerns 
living together and completing each other (Matsumoto \& Juang, 2016). Consequently, greediness and rapacity will slowly disappear from people's minds since they have stopped being egoistic and prioritizing their common objectives.

\section{Session 5 'Stay Together and Happy in Differences'}

The theme discussed in this last session is completing activities together with other ethnic groups. It aims to establish positive dependency and positive cooperation. One of the messages taught in this session is "Urip iku Urup", which means that life is flame. Thus, life should transfer benefits for other people. Someone should carry more substantial benefits for others. After the members learn to cultivate their sense of belonging in the previous session (Phinney, 1992), they are asked to discuss the essentials of sharing. This message emphasizes that living alone is not a wise choice.

To live with personal pride has never been someone's success benchmark. People's success can be more meaningful if they share advantages with other people (Ahmedani, 2011). Their diversity bears considerable opportunities for each individual to help each other. Additionally, it also brings chances for them to complete each other's deficiency (Kamal, 2013) by transferring the enormous benefit toward their kind. In short, this message advises that happiness does not rely on what humans have but on what they have shared with others.

In addition to that, another message was also discussed in this session. The message is "Aja adigang, adigung, adiguna", which means humans should never feel omnipotent and super powerful. It may be similar to the previous statement that tells humans not to act like the smartest person. However, this message accentuates more on the fact that each individual is born equal (Ahmedani, 2011). No one has a superior right or obligation. The closeness the members have shared from the previous session will enhance this concept. They will internalize that, even with different cultures and values, they have the same purpose to fulfill their needs. Thus, being omnipotent and arbitrary is not a noble attitude. Humans have to corporate, support, and complete each other, while also welcome and appreciate each other's (Phinney, 1992).

Those five-sessions can be adopted in the implementation of Dasa Pitutur from Sunan Kalijaga based psychoeducational counseling. As the leader, the counselor should develop the participants' values and social competencies (Corey, 2012; Gladding, 2016; Walsh, 2010). Generally, the Dasa Pitutur from Sunan Kalijaga asks the group members to comprehend, accept, and appreciate their differences (Sakdullah, 2014). Through this psychoeducational, the philosophy within Dasa Pitutur is expected to enhance other group orientation.

\section{CONCLUSION}

The psychoeducational counseling in this study aims to accommodate the Dasa Pitutur values from Sunan Kalijaga, as the local culture, to improve the service's efficacy. Dasa Pitutur advises humans to understand and follow their life process to attain their obligations as social creatures that accentuate their relationship, dependency, and appreciation for other humans. The psychoeducational was divided into five phases to take in ten messages of the Dasa Pitutur values. As the leader, the counselor delivers material from Dasa Pitutur values related to self-behavior upon other people or groups in each session. The first session asks the participants to know themselves to develop their awareness of their culture. In the second session, they are asked to get to know other groups to enhance their understanding of other people's cultures. Meanwhile, in the third session, participants are asked to identify the differences among them to comprehend the dissimilarities among them and be appreciative of that differences. In the fourth session, they learn that even with those differences, they have to unite. It aims to improve their sense of belonging and respect their differences by finding a positive perspective from it. In the last session, they learned to complete activities together with the member of groups from other ethnicity and internalize positive feeling in completing those activities. 


\section{REFERENCES}

Ahmedani, B. K. (2011). Mental health stigma: society, individuals, and the profession. Journal of Social Work Values and Ethics, 8(2), 1-4.

Amin, Z. N., Loekmono, J. T. L., Sofyan, A., \& Mulyawati, V. (2020). Kontribusi identitas etnis dan identitas akademik terhadap subjective well-being mahasiswa. Biblio Couns: Jurnal Kajian Konseling dan Pendidikan, $3(2), 67-73$.

Amin, Z., Wibowo, M., Loekmono, L., Hariyadi, S., \& Isrofin, B. (2017). Ethnic identity and other-group orientation on Javanese and Chinese students. In International Conference on Teacher Training and Education 2017 (ICTTE 2017) (pp. 827-832). Atlantis Press.

Ardila, Y., Sutoyo, A., \& Mulawarman, M. (2019). Keefektifan kelompok psikoedukasi dengan teknik modeling untuk meningkatkan keterampilan sosial siswa. JURNAL EDUKASI: Jurnal Bimbingan Konseling, 5(1), 34-49.

Berg, R. C., Landreth, G. L., \& Fall, K. A. (2018). Group counseling: concepts and procedures (6th ed.). New York: Routledge.

Brown, R. T., Kaslow, N. J., Doepke, K., Buchanan, I., Eckman, J., Baldwin, K., \& Goonan, B. (1993). Psychosocial and family functioning in children with sickle cell syndrome and their mothers. Journal of the American Academy of Child \& Adolescent Psychiatry, 32(3), 545-553.

Corey, G. (2011). Theory and practice of group counseling. Nelson Education.

Corey, G. (2012). Case approach to counseling and psychotherapy. Nelson Education.

Dahir, C. A. (2009). School counseling in the 21 st century: Where lies the future. Journal of Counseling \& Development, 87(1), 3-5.

Dudley, J. R. (2000). Confronting stigma within the services system. Social Work, 45(5), 449.

Gladding, S. T. (2016). Groups: A counseling specialty. Pearson.

Gloria, A. M., \& Hird, J. S. (1999). Influences of ethnic and nonethnic variables on the career decision-making self-efficacy of college students. The Career Development Quarterly, 48(2), 157-174.

Hariko, R., \& Ifdil, I. (2017). Analisis kritik terhadap model KIPAS; Konseling intensif progresif adaptif struktur. Jurnal Konseling dan Pendidikan, 5(2), 109-117.

Henderson, D. A., \& Thompson, C. L. (2016). Counseling children. Nelson Education.

Homan, D. K. (2013). Berpikir dan Berperilaku dengan Rasa. Humaniora, 4(1), 203-211.

Kaelany, H. D. (2000). Islam dan aspek-aspek kemasyarakatan. Jakarta: Bumi Aksara.

Kamal, M. (2013). Pendidikan multikultural bagi masyarakat Indonesia yang majemuk. Al-Ta Lim Journal, 20(3), $451-458$.

Kim, U., Yang, K.-S., \& Hwang, K.-K. (2010). Indigenous and cultural psychology: Memahami orang dalam konteksnya. Yogyakarta: Pustaka Pelajar.

Long, Y., Zhu, S., Quan, F., Yang, Y., \& Zheng, Y. (2020). The impact of ethnic affirmation and belonging on othergroup orientation: The mediating role of personality traits and values in different ethnic groups. Personality and Individual Differences, 152, 109574.

Matsumoto, D., \& Juang, L. (2016). Culture and psychology. Nelson Education.

Mitchell, M. H., \& Gibson, R. L. (2011). Bimbingan dan konseling. Yogyakarta: Pustaka Pelajar.

Myers, D. G., \& Twenge, J. M. (2016). Social psychology. New York: McGraw-Hill, Inc.

Phinney, J. S. (1992). The multigroup ethnic identity measure: A new scale for use with diverse groups. Journal of Adolescent Research, 7(2), 156-176.

Purbasafir, T. F., Fasikha, S. S., \& Saraswati, P. (2018). Psikoedukasi untuk meningkatkan parenting self-efficacy pada ibu anak penyandang autisme. Jurnal Ilmiah Psikologi Terapan, 6(2), 232-244. https://doi.org/10.22219/ jipt.v6i2.7143

Putra, A. S., \& Soetikno, N. (2018). Pengaruh intervensi psikoedukasi untuk meningkatkan achievement goal pada kelompok siswi underachiever. Jurnal Muara Ilmu Sosial, Humaniora, dan Seni, 2(1), 254-261.

Sakdullah, M. (2014). Kidung rumeksa ing wengi karya Sunan Kalijaga dalam kajian teologis. Jurnal THEOLOGIA, 25(2), 231-250.

Sastrapratedja, M. (2012). Hermeneutika dan etika naratif menurut Paul Ricoeur. Kanz Philosophia, 2(2), 247-263.

Setiani, T. P., \& Haryanto, H. C. (2019). Efektivitas psikoedukasi terhadap kemampuan adaptasi sosial pada mahasiswa baru. Psikoislamika: Jurnal Psikologi dan Psikologi Islam, 16(1), 1-8. 
Sobur, A. (2002). Analisis teks media: Suatu pengantar untuk analisis wacana, analisis semiotik dan analisis framing. Remaja Rosdakarya.

Strauss, A., \& Corbin, J. (2013). Dasar-dasar penelitian kualitatif. Yogyakarta: Pustaka Pelajar.

Stuber, J., Meyer, I., \& Link, B. (2008). Stigma, prejudice, discrimination and health. Social Science \& Medicine, 67(3), 351-357. https://doi.org/10.1016/j.socscimed.2008.03.023

Sue, D. W., \& Sue, D. (2008). Counseling the culturally diverse: Theory and practice. John Wiley \& Sons Inc.

Sugiharto, D. Y. P., Hariyadi, S., Amin, Z. N., Mulawarman, M., Muslikah, M., \& Nugraheni, E. P. (2019). Pengembangan kompetensi konselor melalui pelatihan konseling motivational interviewing (MI) berbasis local wisdom budaya jawa. CARADDE: Jurnal Pengabdian Kepada Masyarakat, 1(2), 111-115.

Sumari, M., \& Jalal, F. H. (2008). Cultural issues in counseling: An international perspective. Counselling, Psychotherapy, and Health, 4(1), 24-34.

Torino, G. C., Rivera, D. P., Capodilupo, C. M., Nadal, K. L., \& Sue, D. W. (2018). Microaggression theory: Influence and implications. John Wiley \& Sons.

Walsh, J. F. (2010). Psychoeducation in mental health. Lyceum Books.

World Economic Forum. (2016). The future of jobs: Employment, skills and workforce strategy for the fourth industrial revolution. Global Challenge Insight Report. 